\title{
INFLUENCE OF ECOLOGICAL AND BOTANICAL FACTORS ON THE CULTURE OF BLACK PINE (Pinus nigra) AND PROPOSED FUTURE MANAGEMENT IN ŠUMADIJA REGION (CENTRAL SERBIA)
}

\author{
SEVERIN ŠIKANJA
}

Singidunum University Belgrade, Faculty of Applied Ecology (FUTURA), 83a Požeška St., 11030 Belgrade, Serbia; e-mail:sevke@yahoo.com

\begin{abstract}
Šikanja S.: Influence of ecological and botanical factors on the culture of black pine (Pinus nigra) and proposed future management in Šumadija region (Central Serbia). Ekológia (Bratislava), Vol. 36, No. 2, p. 184-196, 2017.

All ecological aspects have been analysed and studied: botanical factors at black pine cultures in the area of Šmadija. Cultures of black pine of age 33 and 55-60 years within five experimental fields can be found in (1) good habitats, (2) medium habitats and (3) bad habitats were analysed in order to see how the same aged cultures act in different habitats.

We analysed all the plants that appear as terrestrial flora, all the plants that occur as a shrub vegetation and, finally, floor trees. We analysed all the biotic and abiotic factors. The measures for most appropriate care for the cultures of black pine. Black pine in Serbia reaches its highest elevation amplitude in Europe and covers most diverse habitats and soil, mainly because of its visibly pronounced ecological modesty. For this reason, the black pine is one of the most usable kinds of artificial afforestation in the Republic of Serbia at all devastated, treeless terrain in the oak belt, where there is a danger that through the action of erosion, soil degradation occurs. That in the management unit, Gružansko Lepeničke, Jaseničke forests, to answer all the questions, the pine, when it comes to artificially established black lines on the same or on different sites and the same and the various soils, as when it comes to tending these crops. It should be noted that of the 125,000 ha conifer cultures in the Republic of Serbia, 86000 ha of trees were all pines, roughly $70 \%$ of all conifer cultures. Of the 86000 ha pine, 65,200 ha was occupied by black pine, which is about $70 \%$. In the above,Management Unit separate the five sample plots of 25 acres in size.
\end{abstract}

Key words: black pine, cultures, Šumadija, ecological characteristics.

\section{Introduction}

Black pine cultures are spread in our country in various natural conditions, depending not only on geographical, orographic and climate factors but also on geological base, terrain type and herbal communities (Jovanović, 1988). Black pine cultures can be found on limestone, dolomite, serpentine and silica stone, which have high influence on their structure considering certain floristic elements, habitat and the stand solvency (Cedro, 2006). Therefore, black pine cultures are very important in forest theory and practice (Tomić, 2004). However, it 
should be mentioned that huge part of black pine cultures is located in other habitats whose so-called ecological value is higher than black pine needs. In other words, black pine is in the terrain where all soil potential can't be used completely.

The area of black pine cultures in Serbia is 65,200 ha, which is huge amount, considering there is only one species. The total black pine wood volume is $3,099.385 \mathrm{~m}^{3}$, which represents big potential in ecological and economic meaning. Current volume growth for 10 years is $1,435.154 \mathrm{~m}^{3}$. All these facts deserve attention and are also encouraging, but on the other hand, they are huge obligation intruded by forest science (National Forest Inventory, 2012).

\section{Environmental factors}

The aim of this work is to research black pine growth as well as all ecological characteristics of species, which will be dealing with all habitat conditions of researched area. In other words, the aim of this work can be defined like this. Environmental factors can be divided into two groups: (1) biotic factors and (2) abiotic factors. Biotic factors include the impact of plants and animals; abiotic factors include impact land, orography and climate. All these factors work continuously, for a prolonged period, together and affect the growth and increment of the black pine. Environmental factors, profits, volume increase is shown in Fig. 2.

1. To determine the internal structure of black pine stands in the concrete area: thickness, volume, height and the basal area are measured and presented through the graph curves. (The curves are very important to determine how black pine acts in different habitats).

2. To examine the development and growth of individual trees and their influence on culture growth with emphasis on the influence of tree position in the stand on growth dynamics of black pine cultures and duration of production process.

3. To determine the most adequate tending measures, based on all researching results, and as a priority, if it is possible, to determine the optimal rotation duration.

\section{Material and methods}

The research area is the forest management area of Kragujevac (Serbia). This area consists of forestry unit in Gornji Milanovac and one in Kragujevac as well. Concrete measures of black pine cultures were done in the area of GružaLepenica-Jasenica forest, which belongs to forestry unit of Kragujevac.

Gruža-Lepenica's forest is spread over an area of about 2,950 ha. Of this, 590 ha, that is, 20 percent, are black pine cultures. It's quite a large percentage of the black pines, and they deserve special treatment.

Description of habitats: The area of research is with an altitude of 400-470 m, gentle to moderately steep (5-20 $)$ slopes and western and southwestern exposure with unfavourable process of humification, poorly dead forest litter and the substrate of clay, ferruginous and quartz sandstone and serpentinite. The following types of land are defined:

- $\quad$ Eutric brown land is located in the first and third experimental fields.

- $\quad$ Ilimerised acid brown soil is located in second experimental field.

- $\quad$ Eutric silicate land is located in the fourth and fifth experimental fields and is the least productive land.

Forming of five experimental fields had exceptional meaning" because the choice of experimental fields will affect the information we get from the terrain in every way. The size of the each experimental fields is 25 acres (Durkaya et al., 2009).

Included diameter measure, tree height measure and the length of tree top. All data are entered into database. At the get the complete botanical phytocoenological analysis, which will be presented in the research results. The proposed measures are adequate care for the studied areas (Barčić et al., 2010). 


\section{Results}

\section{Phytosociological-botanical classification}

In order to study the floristic composition and phytosociological classification of the origin of the study stands (Table 1), phytocoenological recordings of all sample plots were obtained by using the Braun-Blanquet method.

A detailed survey has shown that artificially established Austrian pine (Pinus nigra Arn.) is located on the site of Hungarian oak forest and oak-cerris Quercetum farnetto Rud.1949. This community belongs in syntaxonomic terms to the class of Querco-Fagetea Br.-Bl. et Vliegen 1937, right Quercetalia pubescentis Br.-Bl. 1932, regarding Quercion farnetto Ht.1954.

According to Tomić (2004), thermophilic deciduous forest of oak and cerris, which belong to this connection, make zonal vegetation of much of South East Europe, affecting mainly the whole Moesian province: Serbia, Macedonia, Bulgaria, Romania and southern parts of eastern Bosnia and northern Greece. The community take lower and hilly parts up to $600 \mathrm{~m}$ above sea level, the plateau and gentle slopes outside the influence of the additional soaking from river valleys.

Together with this, the community of this combination is mainly found in silicate rocks and in different batches of soil humus silicate from acidic brown to luvisol land.

The climate that occurs out if this combination in the communities is extremely continental, with hot summers and cold winters, with annual range of temperature from 21 . The amount of annual precipitation is $500-650 \mathrm{~mm}$, which is less than half compared to the Illyrian floristic geographic province. This area also features a pronounced summer drought period lasting for about 2 months.

The studied artificially established Austrian pines are in more or less flat to moderately sloping terrain, which precisely characterise forest habitat of oak and cerris in the field of Šumadija.

In the studied stands, phytocoenologically recordings were taken, whose botanical composition reveals that these habitats belonging to the former, widespread forests of cerris Quercetum cerris farnetto Rud.1949. The floristic composition reflects the impacts of the three neighbouring floral-geographical regions, that is, vegetation zones: Forest on the north, middle-European-Illiric on the west and sub-Mediterranean in the south.

In the studied, artificially established stands, besides black pine trees in the floor, there are other species such as Quercus cerris, Q. farnetto, Q. virgilliana, Fraxinus ornus and Prunus avium. Almost all of that species in the ecological sense belong to Xerophyte. You can see that Quercus cerris and oak (Q. farnetto) are registered in almost all the experimental fields. In the third experimental field, it can be concluded that the native oaks form a second layer coupled to the first floor of the trees.

Because of enlightened assembly of artificially established stands of red pine, the shrub layer is approximately rich. In addition to these species, in the shrub, there are other xerophilous species such as Crataegus monogyna, Rosa canina, Prunus spinosa, Cornus sanguinea, Pyrus pyraster, Tilia argentea, Ligustrum vulgare, Acer campestre, Sorbus torminalis, Vibur- 
T a b l e 1. Results of phytosociological-botanical studies in cultures of black pine.

\begin{tabular}{|c|c|c|c|c|c|}
\hline \multicolumn{6}{|c|}{ Artificially established Austrian pine (Pinus nigra J.F. Arnold) } \\
\hline Number of recording & 1 & 2 & 3 & 4 & 5 \\
\hline recording date & $19 / 07 / 2014$ & $19 / 07 / 2014$ & $19 / 07 / 2014$ & $19 / 07 / 2014$ & $19 / 07 / 2014$ \\
\hline Field labels & OP1 & OP2 & OP3 & OP4 & OP5 \\
\hline Locality & Popovac & Popovac & Popovac & Klisura & Klisura \\
\hline Management Unit & $\begin{array}{c}\text { Gružansko- } \\
\text { Lepeničko- } \\
\text { Jaseničkeforest }\end{array}$ & $\begin{array}{c}\text { Gružansko- } \\
\text { Lepeničko- } \\
\text { Jaseničke forest }\end{array}$ & $\begin{array}{l}\text { Gružansko- } \\
\text { Lepeničko- } \\
\text { Jaseničke forest }\end{array}$ & $\begin{array}{l}\text { Gružansko- } \\
\text { Lepeničko- } \\
\text { Jaseničke } \\
\text { forest }\end{array}$ & $\begin{array}{c}\text { Gružansko- } \\
\text { Lepeničko- } \\
\text { Jaseničke forest }\end{array}$ \\
\hline Department ( part) & $65 \mathrm{~g}$ & $65 \mathrm{~d}$ & $65 \mathrm{a}$ & $66 \mathrm{a}$ & $66 \mathrm{~b}$ \\
\hline Size pp $\left(\mathrm{m}^{2}\right)$ & 2500 & 2500 & 2500 & 2500 & 2500 \\
\hline Elevation $(\mathrm{m})$ & $400-420$ & $410-430$ & 400 & $420-450$ & $450-530$ \\
\hline Exposition & $\mathrm{W}$ & $\mathrm{E}$ & $\mathrm{W}$ & $\mathrm{W}$ & $\mathrm{W}$ \\
\hline The slope given in ${ }^{0}$ & $5^{0}$ & $10^{0}$ & $5^{0}$ & $10-15^{0}$ & $20-25^{0}$ \\
\hline geological substrates & Glinac & $\begin{array}{l}\text { The ferruginous } \\
\text { - quartz sand- } \\
\text { stone decom- } \\
\text { posing }\end{array}$ & Glinac & Serpentinite & Serpentinite \\
\hline Soil & $\begin{array}{c}\text { Eutric brown } \\
\text { soil-illimerised }\end{array}$ & $\begin{array}{c}\text { Distric brown } \\
\text { soil-illimerised }\end{array}$ & Eutric brown soil & $\begin{array}{c}\text { Eutric } \\
\text { siliceous soil }\end{array}$ & $\begin{array}{c}\text { Eutric siliceous } \\
\text { soil } \\
\end{array}$ \\
\hline \multicolumn{6}{|c|}{ I FLOOR } \\
\hline Set & 0.6 & 0.6 & 0.8 & 0.7 & 0.6 \\
\hline Hight-average (m) & 11.3 & 12.8 & 15.7 & 15.1 & 10.1 \\
\hline $\begin{array}{l}\text { Diametre -average } \\
(\mathrm{cm})\end{array}$ & 16.5 & 19.6 & 31.3 & 29.8 & 16.0 \\
\hline Distance $(\mathrm{m})$ & $2-4$ & $3-5$ & $2-3$ & $3-5$ & $3-5$ \\
\hline Pinus nigra & 5.5 & 4.5 & 3.3 & 4.4 & 3.3 \\
\hline Quercus cerris & & +.1 & 2.2 & 1.1 & 2.3 \\
\hline Quercus farnetto & & 1.1 & 1.1 & 1.1 & 2.3 \\
\hline Quercus virgilliana & & & 1.1 & & \\
\hline Fraxinus ornus & & & & 1.1 & \\
\hline Prunus avium & & & +.1 & & \\
\hline \multicolumn{6}{|c|}{ II FLOOR } \\
\hline Set & 0.3 & 0.4 & 0.6 & 0.4 & 0.4 \\
\hline Height-average (m) & 1.0 & 1.5 & 1.5 & 2.0 & 1.8 \\
\hline Fraxinus ornus & +.1 & +.1 & 1.1 & 2.2 & 1.2 \\
\hline Quercus cerris & +.1 & 1.1 & & 2.2 & 2.2 \\
\hline Quercus farnetto & +.1 & 1.1 & & 2.2 & 2.2 \\
\hline Crataegus monogyna & 1.1 & & 2.2 & 2.2 & 1.2 \\
\hline Prunus avium & 1.1 & 1.1 & 1.1 & 2.1 & \\
\hline Rosa canina & 1.1 & +.1 & +.1 & & 1.1 \\
\hline Prunus spinosa & +.1 & & & 1.2 & 1.1 \\
\hline Cornus sanguinea & 1.2 & & 1.1 & 1.2 & \\
\hline Ulmus carpinifolia & +.1 & & 1.1 & 1.1 & \\
\hline Pyrus pyraster & +.1 & 1.1 & & +.1 & \\
\hline
\end{tabular}


T a b le 1. Continued.

\begin{tabular}{|c|c|c|c|c|c|}
\hline Tilia argentea & +.1 & & +.1 & 1.1 & \\
\hline Rubus caesius & 1.2 & 1.2 & & & \\
\hline Rubus discolor & 1.2 & 1.2 & & & \\
\hline Ligustrum vulgare & & +.2 & 1.2 & & \\
\hline Acer campestre & +.1 & & +.1 & & \\
\hline Robinia pseudoacacia & & +.1 & +.1 & & \\
\hline Sorbus torminalis & & +.1 & +.1 & +.1 & \\
\hline Populus tremula & & +.1 & & & \\
\hline Viburnum lantana & & & +.1 & & \\
\hline Acer tataricum & & & +.1 & & \\
\hline Quercus virgilliana & & & +.1 & & \\
\hline \multicolumn{6}{|c|}{ III FLOOR } \\
\hline cover & 1.0 & 1.0 & 0.3 & 0.7 & 0.7 \\
\hline Rubus caesius & 2.3 & 2.3 & 1.1 & 1.2 & 1.1 \\
\hline $\begin{array}{l}\text { Brachypodium silvati- } \\
\text { cum }\end{array}$ & 2.3 & +.2 & 1.1 & 2.2 & 2.1 \\
\hline Fragaria vesca & 2.2 & +.1 & & 1.1 & 1.1 \\
\hline Calamintha vulgaris & 1.2 & & +.1 & 1.1 & +.1 \\
\hline Prunus spinosa & 1.1 & +.1 & 1.1 & 2.2 & \\
\hline
\end{tabular}

num lantana, Acer tataricum. Owing to the deteriorating edaphic conditions (higher slope, shallower and more skeletal plot), the shrub floor in OP 4 and FP5 is far poorer.

The floor of terrestrial flora floristic composition is very rich. On all five demonstration fields, there were totally about 50 species of plants. The presence of certain plants, such as Rubus caesius, $R$. discolour, Prunus spinosa, Fraxinus ornus, Crataegus monogyna, Acer tataricum, Tilia argentea, Festuca ovina, Dactylis glomerata, Poa nemoralis, Tanacetum corymbosum, Brachypodium silvaticum, Rumex acetosella, Hypericum perforatum, Achillea millefolium, Eupatorium cannabinum, Viccia cracca, Centaurium umbellatum and Populus tremula, indicates a certain degradation processes. Many of these species are characteristic of the enlightened woods and meadows.

The stands that are on the leached soil ( OP 1 and OP 2) is characterised by the greatest wealth of plants. Overall set of two-storey stands (black pine and native oak). The floor of ground flora in OP 3 has the lowest coverage, although there is a deep eutric brown soil.

If we carefully look at Fig. 1, where all height curves from all five experimental fields are shown, we can notice the following:

a. Red height curve, marked as III experimental field I line, is height curve for black pine cultures that are 55 years old. Under it, there is black height curve marked as IV experimental field II line, with the same age of 55 years like the culture just mentioned above. The conclusion is that the height curve values are higher when black pine is in better habitats;

b. Similar situation can be seen with younger cultures. On the same graph, height curve is marked red, I experimental field I line. Under it, there is blue height curve, which is 
marked as V experimental field II line, both cultures are 30 years old. And here, as well, red height curve is above blue one. Experimental fields III and I are on eutric brown soil, the most productive in these researches, whilst experimental fields IV and V are on poor shallow humus-silicate soil. It is obvious that black pine has recognised better habitats soil - which resulted through height curves as a very significant result.

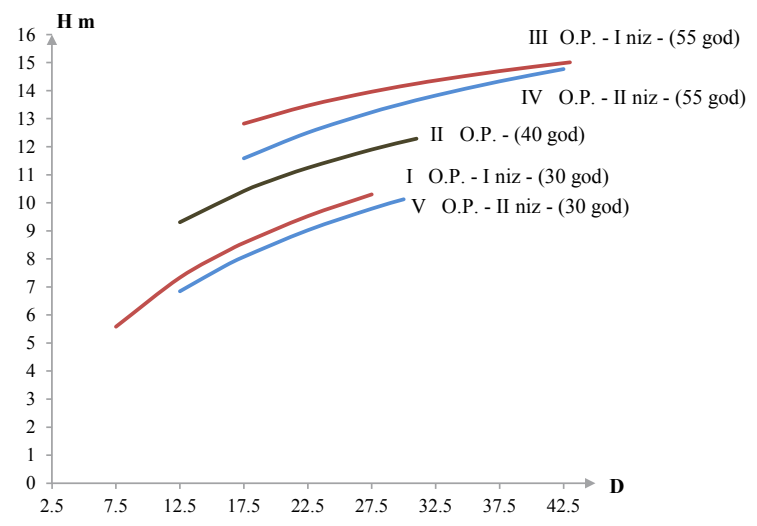

Fig. 1. Height curves for the five experimental fields.

current volume increment

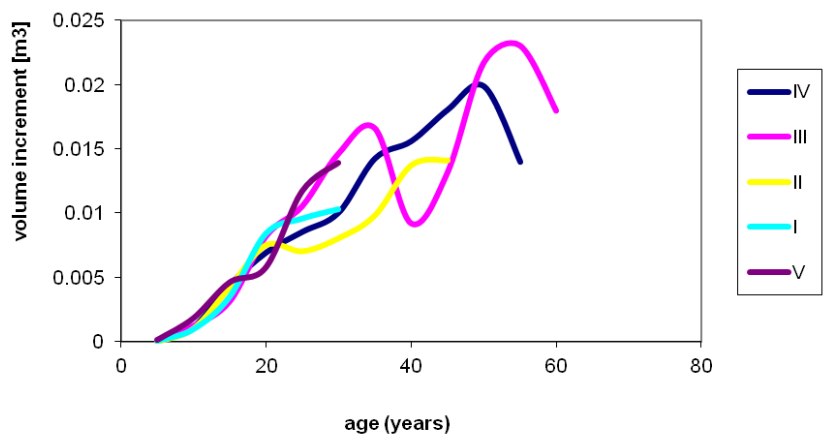

Fig. 2. Graphic display increment volume 5 sample plots.

This is very important indicator for black pine cultures of this area, because it is known that height curves show internal development of the stand. After all, based on every measuring element of every experimental field, it is quite clear that all the consequences of late and inadequate tending are obvious. The primary consequence is, above all, reduced growth; worse culture image, in general; lower vitality; and increased sensitivity to the wind and snow influence. 
At the end, it comes to the increment of all experimental fields (Fig 2). Opposing flows of diameter and height increment, because the former always accumulates the height increment, and diameter, and in the end I increment. Younger culture on the first and fifth experimental fields culminated in about 20-25 years of age. Other experimental field has also the

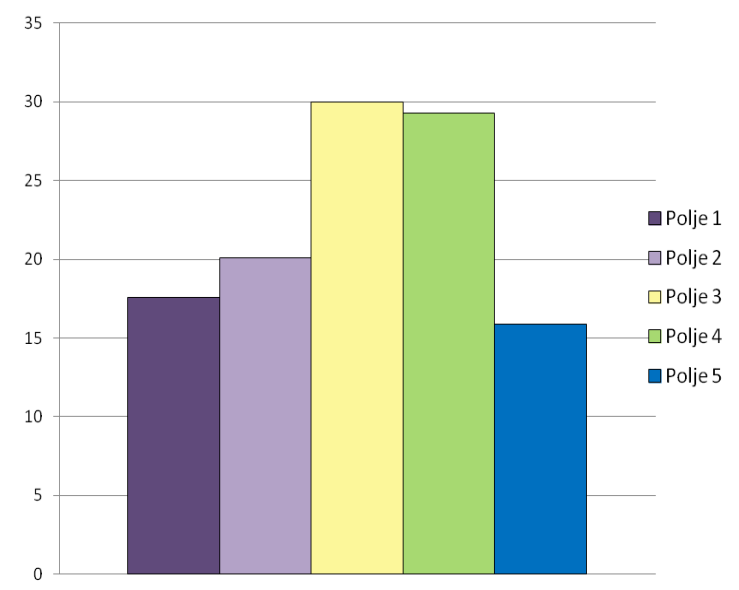

Fig. 3. Influence of ecological and botanical factors, on the diameter $\mathrm{cm}$ black pine in experimental field (5 field). Differences between mean values of between fields were statistically significant ( $p<0.0005$, analysis of variance (ANOVA)). The differences were significant between any two fields and fields 3 and $4(\mathrm{p}=0.940)$ (Dunet). In our sample, field 3 has, on an average, larger diameter $(30.01 \pm 3.98)$ than field $4(29.28 \pm 4.58)$, and this difference was statistically significant (Dunet).

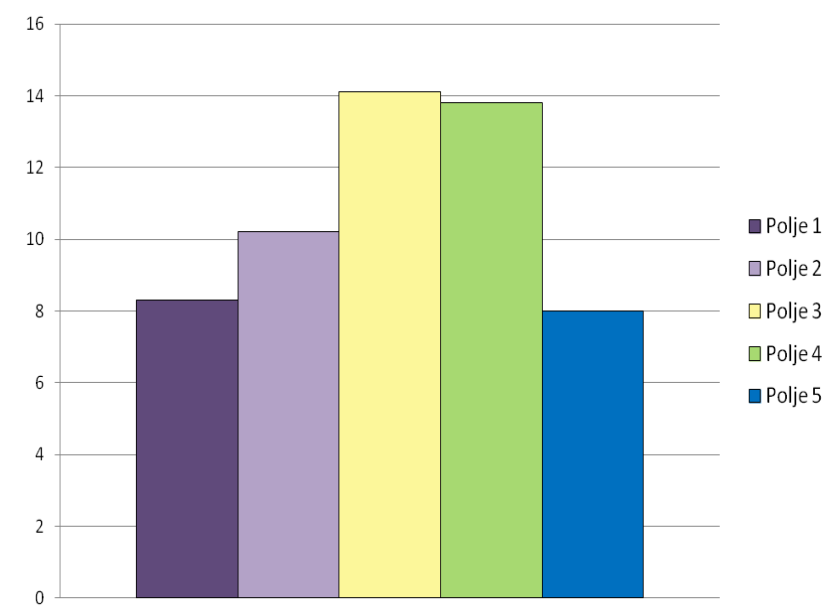

Fig. 4. Influence of ecological and botanical factors, on the height $\mathrm{m}$ black pine in experimental field (5 field). Differences between mean values of height of the stand in the fields were statistically significant $(p<0.0005$, ANOVA). The differences were significant between every two fields (least significant difference, LSD). 
culmination of about 20 years. Whilst with the culture on the third experimental field, we had a noteworthy fact about the culmination of those of 30 years and about 50 years of age. In terms of better habitat, whilst with the same age of the fourth field, the culmination of the Bilas was once, about 50 years old life.

\section{Statistical results}

Statistic analysis determine the connection between the ecological and biological factors and all the rest of interest: relationship and the correlation of length of stands of black pine and the stand. It is proved that thereis a strong statistical correlation amongst all elements, especially between length of stand and the stand, which is given in the curve within each field.

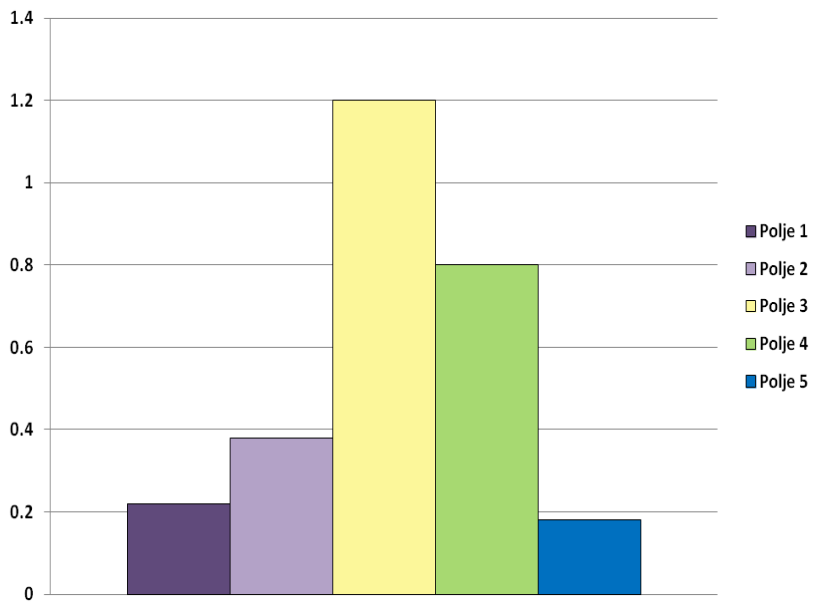

Fig. 5. Influence of ecological and botanical factors, on the volume $\mathrm{m} 3$ black pine in experimental field ( 5 field). The differences between the mean values of the volume of the stand in the fields are statistically significant $(\mathrm{p}<0.0005$, ANOVA). The differences were significant between every two fields (LSD).

\section{Statistical analysis of experimental field}

Experimental field 1:

Model summary

\begin{tabular}{|l|c|c|c|c|}
\hline Model & $\mathrm{R}$ & R Square & Adjusted R Square & Standard Error of the Estimate \\
\hline 1 & $.868^{\mathrm{a}}$ & .753 & .752 & .05123 \\
\hline
\end{tabular}

a Predictors: (Constant), x_3 
ANOVA $^{\mathrm{a}}$

\begin{tabular}{|l|l|c|c|c|c|c|}
\hline \multicolumn{2}{|l|}{ Model } & Sum of Squares & df & Mean Square & F & Significance \\
\hline \multirow{3}{*}{1} & Regression & 2.242 & 1 & 2.242 & 854.359 & $.000^{\mathrm{b}}$ \\
\cline { 2 - 7 } & Residual & .735 & 280 & .003 & & \\
\cline { 2 - 7 } & Total & 2.977 & 281 & & & \\
\hline
\end{tabular}

${ }^{a}$ Dependent Variable: lny

b Predictors: (Constant), x_3

Coefficients $^{\mathrm{a}}$

\begin{tabular}{|c|c|c|c|c|c|c|}
\hline & & \multicolumn{2}{|c|}{ Unstandardised Coefficients } & $\begin{array}{c}\text { Standardised } \\
\text { Coefficients }\end{array}$ & \multirow[t]{2}{*}{$\mathrm{t}$} & \multirow[t]{2}{*}{ Significance } \\
\hline \multicolumn{2}{|c|}{ Model } & B & Standard Error & Beta & & \\
\hline \multirow[t]{2}{*}{1} & (Constant) & 3.462 & .047 & & 73.560 & .000 \\
\hline & x_3 & -3.421 & .117 & -.868 & -29.229 & .000 \\
\hline
\end{tabular}

${ }^{\mathrm{a}}$ Dependent Variable: lny

$\ln \mathrm{a}=\mathrm{A}=3.462, \mathrm{~b}=-3.421$

$\mathrm{a}=31.88$

Curve equation is

$y=3,421 \cdot e^{-\frac{3,421}{\sqrt[8]{x}}}$

\section{Experimental field 2:}

Model summary

\begin{tabular}{|l|c|c|c|c|}
\hline Model & R & R Square & Adjusted R Square & Standard Error of the Estimate \\
\hline 1 & $.750^{\mathrm{a}}$ & .563 & .560 & .04779 \\
\hline
\end{tabular}

a Predictors: (Constant), x_3

ANOVA $^{a}$

\begin{tabular}{|l|l|c|c|c|c|c|}
\hline \multicolumn{2}{|l|}{ Model } & Sum of Squares & df & Mean Square & F & Significance \\
\hline \multirow{3}{*}{1} & Regression & .526 & 1 & .526 & 230.247 & $.000^{\mathrm{b}}$ \\
\cline { 2 - 7 } & Residual & .409 & 179 & .002 & & \\
\cline { 2 - 7 } & Total & .935 & 180 & & & \\
\hline
\end{tabular}

a Dependent Variable: lny

b Predictors: (Constant), x_3

\section{Coefficients $^{\mathrm{a}}$}

\begin{tabular}{|c|c|c|c|c|c|c|}
\hline \multirow[t]{2}{*}{ Model } & & \multicolumn{2}{|c|}{ Unstandardised Coefficients } & $\begin{array}{c}\text { Standardised } \\
\text { Coefficients }\end{array}$ & \multirow[t]{2}{*}{$\mathrm{t}$} & \multirow[t]{2}{*}{ Significance } \\
\hline & & $\mathrm{B}$ & Standard Error & Beta & & \\
\hline \multirow[t]{2}{*}{1} & (Constant) & 3.294 & .060 & & 54.459 & .000 \\
\hline & $x \_3$ & -2.475 & .163 & -.750 & -15.174 & .000 \\
\hline
\end{tabular}

a Dependent Variable: lny 
$\ln \mathrm{a}=\mathrm{A}=3.294, \mathrm{~b}=-2.475$

$\mathrm{a}=26.95$

Curve equation

$y=2,475 \cdot e^{-\frac{2,475}{\sqrt[s]{x}}}$

Experimental field 3:

Model summary

\begin{tabular}{|l|c|c|c|c|}
\hline Model & $\mathrm{R}$ & R Square & Adjusted R Square & Standard Error of the Estimate \\
\hline 1 & $.356^{\mathrm{a}}$ & .127 & .116 & .06622 \\
\hline
\end{tabular}

a Predictors: (Constant), x_3

ANOVA $^{a}$

\begin{tabular}{|l|l|c|c|c|c|c|}
\hline \multicolumn{2}{|l|}{ Model } & Sum of Squares & $\mathrm{df}$ & Mean Square & F & Significance \\
\hline \multirow{3}{*}{1} & Regression & .050 & 1 & .050 & 11.500 & $.001^{\mathrm{b}}$ \\
\cline { 2 - 7 } & Residual & .346 & 79 & .004 & & \\
\cline { 2 - 7 } & Total & .397 & 80 & & & \\
\hline
\end{tabular}

a Dependent Variable: lny

b Predictors: (Constant), x_3

\section{Coefficients $^{\mathrm{a}}$}

\begin{tabular}{|l|c|c|c|c|c|c|}
\hline \multirow{2}{*}{ Model } & \multicolumn{2}{|c|}{ Unstandardised Coefficients } & $\begin{array}{c}\text { Standardised } \\
\text { Coefficients }\end{array}$ & \multirow{2}{*}{$\mathrm{t}$ Significance } \\
\cline { 3 - 7 } \multicolumn{2}{|c|}{} & $\mathrm{B}$ & Standard Error & Beta & & .000 \\
\hline \multirow{2}{*}{1} & (Constant) & 3.159 & .151 & & 20.900 & .001 \\
\cline { 2 - 7 } & $\mathrm{x} \_3$ & -1.583 & .467 & -.356 & -3.391 & \\
\hline
\end{tabular}

a Dependent Variable: lny

$\ln \mathrm{a}=\mathrm{A}=3.159, \mathrm{~b}=-1.583$

$\mathrm{a}=23.55$

Curve equation is

$y=1,583 \cdot e^{-\frac{1,583}{\sqrt[3]{x}}}$

Experimental field 4:

Model summary

\begin{tabular}{|l|c|c|c|c|}
\hline Model & R & R Square & Adjusted R Square & Standard Error of the Estimate \\
\hline 1 & $.868^{\mathrm{a}}$ & .754 & .752 & .02551 \\
\hline
\end{tabular}

a Predictors: (Constant), x_3 
ANOVA $^{a}$

\begin{tabular}{|l|l|c|c|c|c|c|}
\hline \multicolumn{2}{|l|}{ Model } & Sum of Squares & $\mathrm{df}$ & Mean Square & F & Significance \\
\hline \multirow{3}{*}{1} & Regression & .205 & 1 & .205 & 315.807 & $.000^{\mathrm{b}}$ \\
\cline { 2 - 7 } & Residual & .067 & 103 & .001 & & \\
\cline { 2 - 8 } & Total & .273 & 104 & & & \\
\hline
\end{tabular}

${ }^{a}$ Dependent Variable: lny

bPredictors: (Constant), x_3

\begin{tabular}{|c|c|c|c|c|c|c|}
\hline \multicolumn{7}{|c|}{ Coefficients $^{\mathrm{a}}$} \\
\hline \multirow{2}{*}{\multicolumn{2}{|c|}{ Model }} & \multicolumn{2}{|c|}{ Unstandardised Coefficients } & $\begin{array}{c}\text { Standardised } \\
\text { Coefficients }\end{array}$ & \multirow[t]{2}{*}{$\mathrm{t}$} & \multirow[t]{2}{*}{ Sig. } \\
\hline & & $\mathrm{B}$ & Std. Error & Beta & & \\
\hline \multirow[t]{2}{*}{1} & (Constant) & 3.398 & .045 & & 74.862 & .000 \\
\hline & x_3 & -2.469 & .139 & -.868 & -17.771 & .000 \\
\hline
\end{tabular}

$\ln \mathrm{a}=\mathrm{A}=3.398, \mathrm{~b}=-2.469$

$\mathrm{a}=29.90$

Curve equation is

$y=2,469 \cdot e^{-\frac{2,469}{\sqrt[3]{x}}}$

\section{Experimental field 5:}

\begin{tabular}{|l|r|r|r|r|}
\hline \multicolumn{5}{|c|}{ Model summary } \\
\hline Model & R & R Square & Adjusted R Square & Standard Error of the Estimate \\
\hline 1 & $.874^{\mathrm{a}}$ & .763 & .760 & .05409 \\
\hline a Predictors: (Constant), $\mathrm{x} \_3$ &
\end{tabular}

\begin{tabular}{|l|l|c|c|c|c|c|}
\hline \multicolumn{2}{|l|}{ ANOVA $^{\mathrm{a}}$} \\
\hline \multirow{3}{*}{1} & Sum of Squares & $\mathrm{df}$ & Mean Square & F & Significance \\
\cline { 2 - 8 } & Regression & .717 & 1 & .717 & 244.925 & $.000^{\mathrm{b}}$ \\
\cline { 2 - 8 } & Residual & .222 & 76 & .003 & & \\
\cline { 2 - 7 } & Total & .939 & 77 & & & \\
\hline
\end{tabular}

a. Dependent Variable: lny

b. Predictors: (Constant), x_3

\section{Coefficients $^{\mathrm{a}}$}

\begin{tabular}{|c|c|c|c|c|c|c|}
\hline \multirow{2}{*}{\multicolumn{2}{|c|}{ Model }} & \multicolumn{2}{|c|}{ Unstandardised Coefficients } & \multirow{2}{*}{$\begin{array}{c}\text { Standardised } \\
\text { Coefficients }\end{array}$} & \multirow[t]{2}{*}{$\mathrm{t}$} & \multirow[t]{2}{*}{ Significance } \\
\hline & & $\mathrm{B}$ & Standard Error & & & \\
\hline \multirow[t]{2}{*}{1} & (Constant) & 3.453 & .085 & & 40.805 & .000 \\
\hline & $x \_3$ & -3.397 & .217 & -.874 & -15.650 & .000 \\
\hline
\end{tabular}

${ }^{a}$ Dependent Variable: lny 
$\ln \mathrm{a}=\mathrm{A}=3.453, \mathrm{~b}=-3.397$

$\mathrm{a}=31.60$

Curve equation is

$y=3,397 \cdot e^{-\frac{3,397}{\sqrt[3]{x}}}$

Proposal for future management

Process of tending for the first experimental field: IT IS RECOMMENDED: Low thinning - medium strength with thinning intensity of 5-8 years. The action strength by tree number $(\mathrm{N})$ is $33 \%$, basal area (G) $30.36 \%$, volume (V) $30.42 \%$ and current volume growth (Iv) $31.7 \%$.

Process of tending for the second experimental field: IT IS RECOMMENDED: High thinning - with the best tree selection for the future tress, as foundation of future development and growth, with thinning intensity of $8-10$ years. The action strength by tree number $(\mathrm{N})$ is $34.83 \%$, basal area $(\mathrm{G}) 33.12 \%$, volume (V) $33.14 \%$ and current volume growth (Iv) $41.66 \%$.

Process of tending for the third experimental field: IT IS RECOMMENDED: Selective thinning - moderate strength with selection for the future tress and with thinning intensity of 5-8 years.

Process of tending for the fourth experimental field: IT IS RECOMMENDED: Stronger selective thinning - with selection of certain trees of future numbers and with thinning intensity of $8-10$ years. The action strength by tree numbers $(N)$ is $32.38 \%$, basal area $(G) 28.39 \%$, volume V 28.41\% and current volume growth (Iv) $36.25 \%$.

Process of tending for the fifth experimental field: IT IS RECOMMENDED: Stronger thinning, in order to remove every low quality phenotype, with thinning intensity of 5-8 years. The action strength by tree numbers $(\mathrm{N})$ is $37.66 \%$, basal area $(\mathrm{G}) 32.88 \%$, volume $(\mathrm{V})$ $31.69 \%$ and current volume growth (Iv) $31.84 \%$.

\section{Conclusion and discussion}

Conducted research and analysis show that there are many strong reasons for monitoring the vitality of forests and forecast their future development. Monitoring activities should be complex and constant, whereby it is necessary to include the typical natural and businesses, especially those that are already indication, tending to distort the natural balance and revitalisation.

The knowledge of the need for ongoing security stability of forest ecosystems, and thus the existential basis of forestry, indicates the need for in-depth research and monitoring increment of forest trees as a complex reaction trees on stimulating and disruptive action of exogenous and endogenous factors.

Advocating for experienced, well-established procedures and schemata in forest management, as the basis of rational forestry, it must be replaced by the new active approach directed towards learning from nature and supporting only those natural processes acceptable for a man. This leads to a better implementation of environmental ethics and the boundaries between classical forestry and applied ecology. If not improving considerably more complex 
and expensive system of forest management used only in the event that there is a material base.

From the analysis of cultures of black pine from the studied territory in central Serbia, it can be concluded that:

- healthy and mushroom-infected plot stands differ in population and the composition of soil microflora, amongst other things, defining the ways how to look for the causes of fungus expansion,

- infected stand soil culture (33 years old) is very low,

- from-older, infected culture (55 years old), the number of ammonification microorganisms is slightly higher compared to that of younger, infected culture and oligonitophilic microorganisms, compared to younger culture, occurred in vast populations. Fungi and actinomycetes are represented in slightly greater numbers than those in the younger stand culture.

It is worthy to note that in 33-year-old healthy stands, the total number of microorganisms was greater than the ammonification and oligonitophilic microorganisms. Mushrooms and actinomycetes were represented in higher numbers.

In 55-year-old healthy stands, the total number of microorganisms was greater than that of ammonification and oligonitophilic microorganisms that showed a slightly higher population than younger healthy culture Fungi and actinomycetes were represented here in even greater numbers.

Survey of all taxation elements within each field was conducted. The volume, diameter and height increment in categories such as total, average and current gain were determined. Access to appropriate care measure was determined. Field could clearly see that sometimes delayed and the tending. artificially established on the territory of this, it would be a general conclusion. Should cultivate, to the real meaning of the end of the breeding behaviour, and that in time, back to the indigenous areas, which used to be, and it's oak, which is economically profitable, and biologically stronger species of pine.

\section{References}

Barčić, D., Španjol, Ž. \& Rosavec R. (2010). Impact on site and development of black pine (Pinus nigra J.F.Arnold) forest cultures in the submediterannean karst area. Croatia Journal of Forest Engineering, 32(1), 131-140.

Cedro, A. (2006). Comparative dendroclimatological studies of the impact of temperature and rainfall on Pinus nigra Arnold and Pinus sylvestris in Northwestern Poland. Baltic Forestry, 12(1), 110-116.

Durkaya, A., Durkaya, B. \& Unsal A. (2009). Predicting the above-ground biomass of calabrian pine (Pinus brutia Ten.) stands in Turkey. African Journal of Biotechnology, 8(11), 2483-2488. http://www.academicjournals.org/ AJB

Jovanović, S. (1988). Forest growing. Belgrade.

National Forest Inventory, (2012). Belgrade.

Tomić, Z. (2004). Phytocenology classbook. Belgrade. 